\title{
Analysis of Factors Contributing to Motivation of Lecturers; The Case of Faculty Communication and Business in Telkom University.
}

\author{
Hardita Maylasari \\ Telkom University \\ hmaylasari@gmail.com \\ Yahya Arwiyah \\ Telkom University \\ yahya@telkomuniversity.ac.id
}

\author{
Astadi Pangarso \\ Telkom University \\ astadipangarso@telkomuniversity.ac.id
}

\begin{abstract}
The purpose of this research is to know the motivation conditions as well as to look at the factors that contributes that dominant factor and contribute to the motivation permanent lectures on Faculty Communication and Business of Telkom University. The research method is descriptive quantitative. The respondent in this study is permanent lectures on Faculty Communication and Business of Telkom University. Factor in this research totaled ten factors, consisting of quality supervision, existence, company policy, a good working place, relationships with co-workers, promotion, growth, recognition, obligations, and goal. Research data obtained from the dissemination of the questionnaire to 70 respondents and study of literature. Analytical using data techniques is descriptive analysis and analysis of the factors. Based on the results of the descriptive analysis, the motivation permanent lectures on the category "good" that amounted to $71 \%$. The results of the analysis of the factors mentioned that promotion factor and goal factor is the factor that formed after the reduction of the ten factors. Promotion factor represented by company policy, recognition, quality supervision, relationships with coworkers, growth, and existence has value loading factor is 0,874 . While the goal factor represented by a good working place and obligations has highest value loading factor is 0,924 .
\end{abstract}

Keywords: Motivation, Promotion, Goal, Education 
Tujuan dari penelitian ini adalah untuk mengetahui kondisi motivasi serta untuk melihat faktor yang berkontribusi dan faktor yang dominan dalam berkontribusi pada motivasi dosen tetap Fakultas Komunikasi dan Bisnis Universitas Telkom. Metode penelitian yang digunakan adalah kuantitatif deskriptif. Responden dalam penelitian ini adalah dosen tetap Fakultas Komunikasi dan Bisnis Universitas Telkom. Faktor pada penelitian ini berjumlah sepuluh faktor, terdiri dari mutu pengawasan, existence, kebijakan perusahaan, tempat kerja yang baik, hubungan dengan rekan kerja, promosi, growth, pengakuan, kewajiban, dan tujuan. Data penelitian didapatkan dari penyebaran kuesioner kepada 70 responden dan studi pustaka. Teknik analisis data menggunakan analisis deskriptif dan analisis faktor. Berdasarkan hasil analisis deskriptif, motivasi dosen tetap berada pada kategori "baik" yaitu sebesar $71 \%$. Hasil analisis faktor menyebutkan bahwa faktor promosi dan faktor tujuan merupakan faktor yang terbentuk setelah mereduksi sepuluh faktor. Faktor promosi yang diwakilkan oleh faktor kebijakan perusahaan, pengakuan, mutu pengawasan, hubungan dengan rekan kerja, growth, dan existence yang memiliki nilai loading factor yaitu sebesar 0,874. Sedangkan faktor tujuan yang diwakilkan oleh faktor tempat kerja yang baik dan kewajiban memiliki nilai loading factor tertinggi yaitu sebesar 0,924.

Kata Kunci : Motivasi kerja, Promosi, Tujuan, Dosen Tetap

\section{Introduction}

In the year of 2015 to 2016, education service in Indonesia has grown tremendously. This is evidenced with the growing number of private education as proof especially private universities. According to Act No. 12 of 2012 on Higher Education, a private university college is publicly established and/or held by forming governing body of non-profit legal entities, such as foundation. This foundation has lead to Telkom University establishement as one of the private university located in West Java.Telkom University has seven faculties; one of them is the Faculty of Communication and Business. The vision of this faculty is to become an international faculty in the field of communications and information technology-based business. One of the goals to achieve this vision is to develop and disseminate knowledge in the field of communications and information technology-based business. To achieve these goals, the faculty of communication and business needs to have qualified human resources, especially lecturers.

To enhance the role, duties and responsibilities, lecturers should be encouraged by presence of motivation. According to Sondra P. Siagian (2008), one indicator of 
motivation can be seen from the lecturer's sense of responsibility in doing Tridharma or the main duties of a lecturer in Indonesia which comprised of teaching, research, and community service in accordance with the Performance Standards Institute (SKI). In fact, the lecturer's responsibilities in the Faculty of Communication and Business in doing Tridharma have not met the Performance Standards Institute (SKI). Meanwhile, according to Asep and Tanjung (2004), Indicator of motivation can be seen from the attendance of lecturers in teaching. Based on Coordination Meeting Assisted Class Semester, Academic Year 2014/2015 Telkom University, lecturer's attendance standards while teaching at $96 \%$. In reality, there are lecturers who have not met the presence that is equal to $96 \%$. In other studies, it can be seen that the Business Administration department as part of the Faculty of Communication and Business also needs improvement in terms of motivation. It also contributes to the reason for the importance of research on motivation of lecturer in Faculty of Communication and Business.

Based on above explanation, it can be seen that the attendance and responsibilities of lecturers as seen from Tridharma have not reached the standards prescribed by the University and previous research. Thus, it is necessary to know the motivation of lecturers of the Faculty of Communication and Business, the factors that contribute to motivation permanent lecturers, as well as the dominant factor that contributed to motivation of the permanent lecturer.

\section{Theoritical Framework}

This research will use motivation theories as the base of the study. Robbin and Judge (2015) states that motivation is a process that explains the strength, direction, and persistence of a person in an attempt to achieve the goal. Motivation as thrust that resulted in someone being willing and voluntary to exert the ability, energy, and time in order to achieve predetermined objectives (Siagian, 2004).

According to Herzberg (in Robbin dan Judge, 2015). There are factors contributing to motivation. The first factor is maintaining factor which include six subfactor. First is quality control, which is an activity to ascertain whether the policy in terms of quality (standard) can be reflected in the final outcome (Assauri, 2008: 299). Second is the wages. Wages is one of important elements that can affect the performance of employees, because the salary is a tool to meet the various needs of employees, salaries paid to employees will motivate them to work harder (Hariandja, 2002). Third is the company's policy is a guideline or a policy that limits the behavior of employees in the company (Ivancevich, 2010). Fourth, is the physical working 
environment. If the physical condition of work is in good condition (e.g. clean and attractive or comfortable working environment) then one would be easier to do their job. If working condition is bad, the employee will have difficulty in carrying out the work (Luthans, 2011). Another factor is relationship in the workplace. Relationships with coworkers is having a harmonious working relationship, created on the awareness and willingness to merge in order to achieve common interests (Hasibuan, 2012). Lastly is the job security. Job security is having a job that provides security, protects from physical harms or hazardous conditions (Luthans, 2011: 160)

The second motivation factors include four components. First is work promotion. Promotion is a motivation or a drive for employees to improve his service further in carrying out the task (Manullang, 2004). The second is opportunities of personal growth is a process of improving the technical skills, theoretical, conceptual, and morale of employees through education and training (Hasibuan, 2012). The third is acknowledgement of achievement. Acknowledgement is giving award and proper recognition upon employee's work achievement. (Hasibuan, 2012). Third components is the responsibility. Responsibility is an obligation to give answer upon result that has been done (Istanto, 1994). Lastly is on the achievement of process to achieve goal with hard work.

Siagian (2008) also add the factors that contribute to motivation to be the drive, willingness, readiness, shaping of expertise, responsibility, obligation and goal. Drive is an instinct, only a comprehensive push to from a comprehensive power boost to a common direction. The method that is used in achieving satisfaction towards a drive is different from one individual to other individuals. It depends on each background and culture. Willingness is a resulted desire to achieve certain goal based on knowledge that is influenced by intelligence and energy. (Richard Dewey dan W.J. Humber cited by Mu'in, 2011). Voluntary is a readiness upon other's people deman to grant their wishes without feeling forced. Voluntary in organization means working hard and giving up time and energy for work.Shaping expertise is the process of creating knowledge and proficiency in a job, while shaping ability is the process of creating the ability of a person to a thing that covers all skills, attitudes, values, and understanding that everything is considered as something that is important to the success in task completion (Rusyadi in Yanto: 2005). Responsibility is an obligation to give answer for things that have been done (Istanto, 1994). Obligation is something that must be done and goal is a condition that is expected and intended to make it real.

Previous literature by Flippo (in Hasibuan, 2003) on the factors that contribute to motivation stated that there are nine factors that should contribute to the motivation, 
namely: proper wages, opportunity to advance, promotion, recognition, security, workplace, relationship, recognition and treatment as employee.

Proper wages are rewards to workers who do the grunt work and more reliant on physical strength and the amount of wages is usually determined on a daily basis, unit or bulk (Soemarso, 2009). The opportunity to move forward is an opportunity to advance within the organization known as promotion or increase in the level of office (Heidjrachman, 1992). Promotion is when an employee is transferred from one job to another is greater responsibilities, its level in the hierarchy of positions higher and the income was greater. (Siagian, 2014). Recognition as an individual is rewarding and recognizing appropriate and reasonable for the achievements accomplished by individuals working (Hasibuan, 2012). Security is providing security, protecting from physical harm or hazardous conditions (Luthans, 2011). A workplace is good if there is good work condition (e.g. clean and attractive work environment, or comfortable). In good work environment, an individual will can complete their job easier. If work condition is bad, employee will face difficulty in doing their job. (Luthans, 2011). Acceptance by the group is the close relationship of co-workers that can create acceptance by the group, a good working atmosphere, mutual trust, mutual cooperation, mutual love and respect, brotherhood, mutual encouragement and spirit, and exchange information about job. (Simamora, 2004). Proper treatment is when an individual in life, including in employment expects fair, reasonable, and normal treatment. (Robbin and Judge, 2015). Recognition of achievement is a proper rewarding and recognizing employee's performance properly (Hasibuan, 2012: 147)

In line with prevous researches, Clayton (in Kreitner dan Kinicki, 2014) came up with three factors that contribute to motivation. First is Existence is a person's need to be met and maintain the presence of him as a man in the midst of the people or companies. Existence includes psychological needs (hunger, thirst, and sleep) and safety needs. Second is Relatedness is the relationship between a person with the surrounding social environment. In theory of relatedness this relatedness covers all the needs that involve one's relationship with other. Lastly, Growth is a need to grow and this development is a need that is associated with development of individuals such as creativity and personal. This need is comparable to need of self esteem and self actualization.

Based on previous literatures of experts who argued about the factors that contribute to motivation, a thinking framework is developed. These factors were then grouped. The aim is to group them into one or two factors because they have in common and correlated (Santoso, 2012). Here is the result of the grouping of the factors made into the framework. 


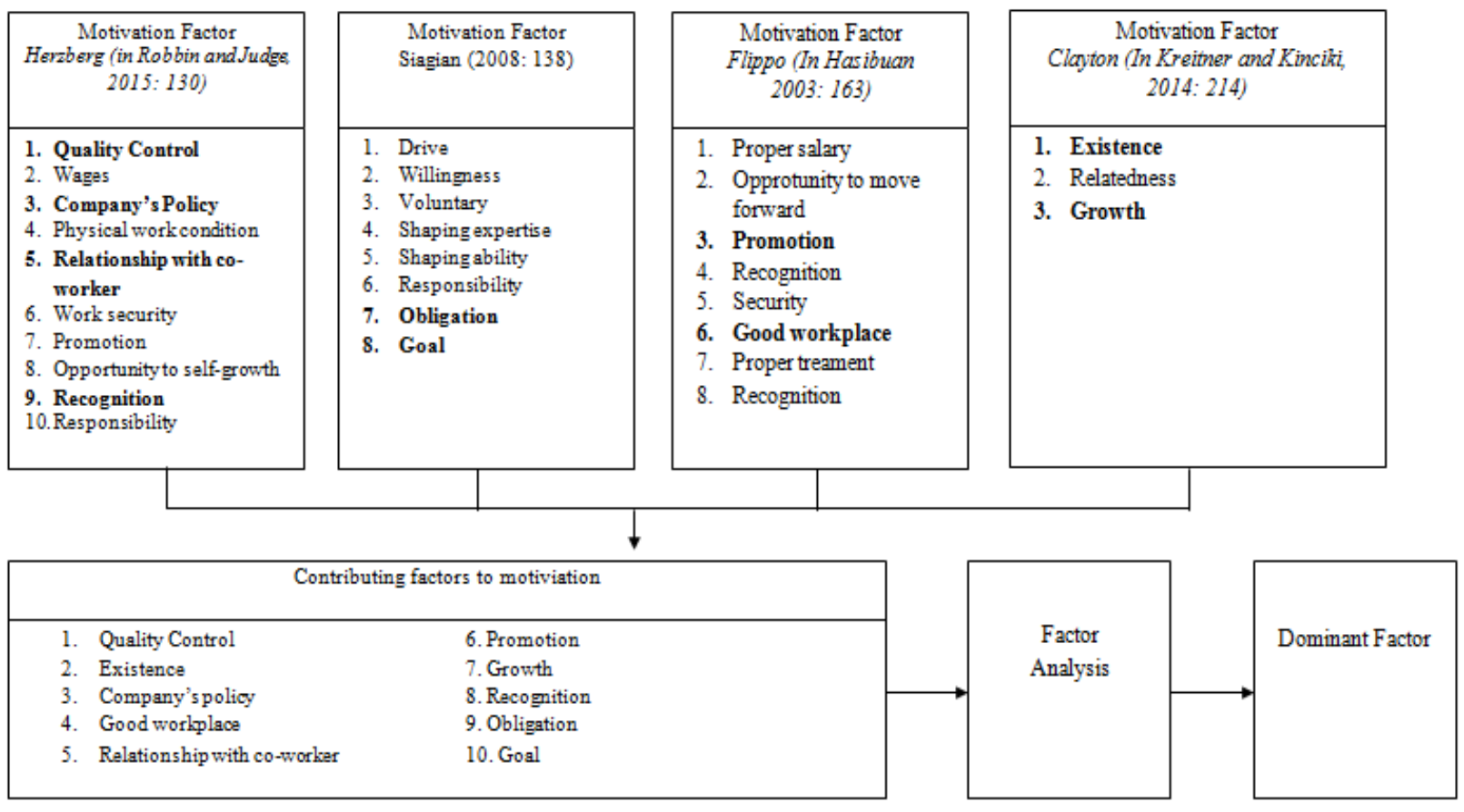

Figure 1. Framework

\section{Methodology}

This research is a descriptive research with quantitative approach. The analysis of the data uses descriptive analysis and factor analysis. This study uses Likert scale with a score of 1-5 (strongly disagree - strongly agree). Samples in this study are 70 lecturers of the Faculty of Communication and Business Telkom University.

\section{Result and Analysis}

Descriptive Analysis

Table 1. Respondent's Response on Motivation in general

\begin{tabular}{|c|c|c|c|c|c|}
\hline No & Sub Variable & $\begin{array}{c}\text { Total } \\
\text { Score }\end{array}$ & $\begin{array}{c}\text { Ideal } \\
\text { Score }\end{array}$ & $\begin{array}{c}\text { Average } \\
(\%)\end{array}$ & Category \\
\hline 1. & Quality Control & 771 & 1050 & $73,6 \%$ & Good \\
\hline 2. & Existence & 1526 & 2100 & $72,8 \%$ & Good \\
\hline 3. & Company's Policy & 719 & 1050 & $68,3 \%$ & Good \\
\hline 4. & Good Work Place & 530 & 700 & $75,5 \%$ & Good \\
\hline 5. & $\begin{array}{c}\text { Relationship with co- } \\
\text { workers }\end{array}$ & 966 & 1400 & $68,7 \%$ & Good \\
\hline 6. & Promotion & 1135 & 1750 & $64,6 \%$ & Pretty Good \\
\hline 7. & Growth & 1284 & 1750 & $73,2 \%$ & Good \\
\hline 8. & Recognition & 1221 & 1750 & $69,8 \%$ & Good \\
\hline 9. & Obligation & 934 & 1400 & $66,7 \%$ & Pretty Good \\
\hline 10. & Goal & 1090 & 1400 & $78 \%$ & Good \\
\hline
\end{tabular}




\begin{tabular}{|c|r|}
\hline Sum of Total Score & 10176 \\
\hline Average & $72 \%$ \\
\hline
\end{tabular}

Based on the descriptive analysis, motivation of permanent lecturer is in the category of "good" by $71 \%$. With the highest factor that is factor of interest of $78 \%$. Promotion factor and Obligation factor are on category of "good enough". Promotion factor has little value because the lecturers still have two careers, namely the structural and functional positions. In this case, the lecturer is more focused to enhance a career in a functional position. While the obligation factor has little value as a lecturer working on campus with a flexible time schedule because of different schedule.

Factor Analysis

\begin{tabular}{|c|c|c|}
\hline \multicolumn{2}{|c|}{ Kaiser-Meyer-Olkin Measure of Sampling Adequacy. } & 877 \\
\hline \multirow{3}{*}{ Bartlett's Test of Sphericity } & Approx. Chi-Square & 534,885 \\
\hline & df & 45 \\
\hline & Sig. &, 000 \\
\hline
\end{tabular}

Figure 2. KMO \& Barlett's Test

$\mathrm{KMO}$ is used to see whether a factor can be analyzed or not. Based on Figure 2, $\mathrm{KMO}$ of this research is 0,877 with significance level on 0,000 . It means that all ten factors can be analyzed.

\begin{tabular}{|l|rr|}
\multirow{2}{*}{} & \multicolumn{2}{|c|}{ Component } \\
\cline { 2 - 3 } & \multicolumn{2}{|c|}{1} \\
\hline Quality Control &, 788 &, 201 \\
Existence &, 621 &, 479 \\
Company's Policy &, 864 &, 098 \\
Good workplace &, 458 &, 741 \\
Relations with Co-Worker &, 744 &, 460 \\
Promotion &, 874 &, 141 \\
Growth &, 738 &, 424 \\
Recognition &, 846 &, 233 \\
Responsibility &, 581 &, 647 \\
Goal &,- 030 &, 924 \\
\hline
\end{tabular}

Figure 3: Rotation Factor

The naming of factor can be seen based on the highest loading factor (Supranto, 2010: 326). According to rotation factor, factor with the highest factor loading in the component 1 is promotion factor, meanwhile, the highest factor loading value is in the component 2 that is goal factor. Below is discussion of result of factor analysis: 


\section{Promotion Factor}

Promotion factor has the highest factor loading value on the component 1 in the amount of 0.874 which includes six items, among them are: the company's policy (.864), recognition (0.846) and quality control (0.788), relationship with coworkers (0.744), growth (0.738) and existence (0.621). Thus the factors that contribute to motivation of lecturer of the Faculty of Communication and Business, University of Telkom include: company's policy, recognition, quality supervision, relationships with colleagues, growth, and existence.

a. Company's Policy

The company's policy is associated with the guidelines that limit the behavior of lecturers at the institution (Ivancevich, 2010: 17) [8]. The company's policy implemented along with policies regarding promotion and compensation are clear and understood by the lecturer of the Faculty of Communication and Business, University of Telkom.

b. Recognition

Recognition is associated with appropriate and reasonable reward and recognition for the work achievements of the lecturer (Hasibuan, 2012: 147) [5]. Recognition is implemented with the leaders giving attention and appreciation of the achievements of the lecturers. Furthermore, lecturers can participate in decision-making in a meeting.

c. Quality Control

Quality control associated with activities to ascertain if the policy in terms of quality (standard) can be reflected in the final result (Assauri, 2008: 299) [2]. Quality control is implemented by the leader giving information on everything related to work accomplishment.

d. Relations with coworker

Relations with co-worker, associated with harmonious work relations, is created on the basis of awareness and willingness to merge in order to achieve common interests (Hasibuan, 2012: 137) [5]. Relations with co-worker are implemented by having good relations between leaders and lecturers both inside and outside workplace.

e. Growth

Growth is associated with the need for the development of potential lecturers (Clayton in Kreitner and Kinicki, 2014: 214) [15]. Growth is implemented by the institution providing the opportunity for lecturers to develop their potential, expertise, and skills, which are educated and financed by the institution. 
f. Existence

Existence that is associated with the lecturer needs to be met and maintained its presence of individual as a human being in the middle of the community or institution (Clayton in Kreitner and Kinicki, 2014: 214). Existence is implemented by institutions providing security and health to the lecturers. As well as, faculty salaries earned in accordance with the job (Tridharma) has done.

\section{Objective Factors}

Objective factor has the highest value of loading factor that is equal to 0.924 on component 2 that includes two items, namely: good workplace (0.741), and obligation (0.647). Thus the factors that contribute to motivation lecturer of the Faculty of Communication and Business, University of Telkom include: good workplace and responsibility.

a. Good workplace

If there is a good workplace which is associated to working conditions (eg clean and attractive or comfortable working environment), the lecturers will be easier to complete their job, and vice versa (Luthans, 2011: 143). Good workplace is implemented by having nice and pleasant workplaces and facilities adequate support in the working environment.

b. Responsibility

Responsibility is related to something that must be met for accomplishing a work achievement and it must be completed by the lecturer. The responsibility is implemented through duties and responsibilities given institutions in accordance with educational backgrounds and abilities of lecturers. And lecturers also need to prioritize more the interests of the institution than private interests.

\section{Conclusion}

Based on the analysis and data processing on "Analysis of Factors Contributing In Motivation In Fulltime Faculty of Communication and Business, University of Telkom" research, it can be concluded as follows that the condition or situation of lecturer's motivation in the Faculty of Communication and Business, University of Telkom is in the category of "good". Where the highest to the lowest percentage of the dimension that is the goal, good workplace, quality control, growth, existence, recognition, relationships with coworker, company's policies, obligations, and promotion. 
Secondly factors that contribute to the motivation of lecturers of the Faculty of Communication and Business, University of Telkom includes. Promotion factor, consisting of company's policy, recognition, quality supervision, relationships with colleagues, growth, and existence.Another factor is Objective factor which made up the good work and obligations. The dominant factor that contributes to the motivation of lecturers in the Faculty of Communication and Business, University of Telkom is objective factor destination that has the highest factor loading value 0.924 .

\section{References}

Asep, I. T. (2004). Manajemen Motivasi. Jakarta: PT. Gramedia Widiasarana Indonesia.

Assauri, S. (2008). Manajemen Produksi Dan Operasi. Jakarta: LPFEUI.

Hariandja, M. (2002). Manajemen Sumber Daya Manusia. Jakarta: Grasindo.

Hasibuan, M. (2003). Manajemen Sumber Daya Manusia. Jakarta: Bumi Aksara.

Hasibuan, M. (2012). Manajemen Sumber Daya Manusia. Jakarta: Bumi Aksara.

Heidjrarachman, H. S. (1992). Manajemen Personalia. Yogyakarta: BPFE Universitas Gajah Mada.

Istanto, S. (1994). Hukum Internasional. Yogyakarta: Universitas Atmajaya.

Ivancevich, J. (2010). Human Resource Management. New York: McGraw-Hill.

Luthans, F. (2011). Organizational Behavior, 12th ed. New York: McGraw-Hill.

Manullang, M. (2004). Manajemen Personalia. Yogyakarta: Gadjah Mada University Press.

Mu'in, F. (2011). Pendidikan Karakter : Konstruksi Teoritik dan Praktik. Yogyakarta: ArRuzz Media.

Pangarso, A. (2014). "Motivasi Kerja Dosen Program Studi (Prodi) Administrasi Bisnis (Adbis) Sekolah Administrasi Bisnis dan Keuangan (SABK) Institut Manajemen Telkom (IMTelkom) Bandung." Jurnal Administrasi Bisnis Vol 2 No. 3 Universitas Diponegoro, Semarang.

Pengertian Daya Pendorong. Dipetik Februari 11, 2016, dari Kabar Pendidikan: www.kabarpendidikan.co.id

Republik Indonesia. (2012). UU No. 12 Tahun 2012 tentang Pendidikan Tinggi. Jakarta: Sekretariat Negara.

Robert Kreitner, A. K. (2014). Perilaku Organisasi. Jakarta: Salemba Empat. 
Santoso, S. (2012). Aplikasi SPSS Pada Statistik Multivariat. Jakarta: PT. Elex Media Komputindo.

Siagian, S. P. (2004). Manajemen Sumber Daya Manusia. Jakarta: Bumi Aksara.

Siagian, S. P. (2008). Manajemen Sumber Daya Manusia. Jakarta: Bumi Aksara.

Siagian, S. P. (2014). Manajemen Sumber Daya Manusia. Jakarta: Bumi Aksara.

Simamora, H. (2004). Manajemen Sumber Daya Manusia Edisi Ke-3. Yogyakarta: STIE YKPN.

Soemarso. (2009). Akuntansi Suatu Pengantar. Edisi Kelima. Jakarta: Salemba Empat.

Stephen, R. (2015). Perilaku Organisasi. Jakarta: Salemba Empat.

Suliyanto. (2005). Metode Riset Bisnis. Bandung: Alfabeta.

Supranto, J. (2010). Analisis Multivariate Arti \& Interpretasi. Jakarta: Rineka Cipta. 